\title{
The First Modern Pharmacy in Banja Luka: The Brammer Family, Three Generations of Pharmacists
}

\author{
Vanda Marković-Peković ${ }^{1}$
}

\begin{abstract}
Pharmacy activity in Bosnia and Herzegovina was regulated in 1879 by an Order of the Provincial Government, at the beginning of the Austro-Hungarian occupation. The pharmacy owner had to have a doctorate in chemistry or a master's degree in pharmacy obtained at an Austro-Hungarian faculty. The Law on Pharmacies was adopted in 1907.

The first modern pharmacy in Banja Luka was opened by Moritz Brammer in 1879. The pharmacy was inherited by his son Robert, who had sons, Ernest, Hans and Alfred, pharmacists. Ernest inherited father's pharmacy, where he worked as of 1921. Hans, also a writer and a publicist, worked in this pharmacy (1921-1930). He emigrated to Israel in 1949. Before World War II, Alfred owned a pharmacy and a drugstore in Zagreb. The Brammer family, a well-known one in Banja Luka, contributed greatly to the cultural and social development of the city in the time in which they lived.
\end{abstract}

Key words: Banja Luka; History of pharmacy; Brammer family.
(1) Department of Social Pharmacy and Pharmaceutical Legislation Faculty of Medicine University of Banja Luka, Banja Luka, Republic of Srpska, Bosnia and Herzegovina.

Correspondence:

VANDA MARKOVIĆ-PEKOVIĆ

E: vanda.markovic-pekovic@med.unibl.org

\section{ARTICLE INFO}

Received: 8 October 2020 Accepted: 19 October 2020

\section{Introduction}

Little attention was paid to the health of the population during the Ottoman rule, so the health and hygiene conditions of the population were poor. There were very few trained medical professionals and patients were entrusted to ignorant, often speculative people without any medical education, except for some doctors who were educated at the Imperial Military School of Medicine in Constantinople and thus people's health and lives were often victims of their ignorance. ${ }^{1}$ However, there were many barbers (they presented themselves as surgeons), charms, sorcerers, Jewish doctors-hakims, Jewish and Muslim attar-druggists, traditional and herbal drug sellers. The Austro-Hungarian authorities tried to suppress quackery and forbade such people to work. ${ }^{2}$
Austro-Hungarian Monarchy had great impact on healthcare in Bosnia and Herzegovina as the health conditions in the country changed significantly. At the beginning of the occupation, the Austro-Hungarian government sent a public invitation to all interested educated personnel in the Monarchy to settle in Bosnia and Herzegovina. Among the first to settle were Austrians, Germans, Hungarians, Ashkenazi Jews, Poles and Czechs, experts in various professions, including doctors, veterinarians and pharmacists. ${ }^{3}$ This period marked a significant reversal, as the Europeanisation of medicine and pharmacy began from that time. The organisation of the health service according to the canons that ruled in the Monarchy itself was approached at the very beginning. 
The pharmacy service was regulated in 1879 by the Order of the Provincial Government, as a craft rather than a health service. For an independent management of the pharmacy the owner or provisor had to have a doctor's degree in chemistry or a master's degree in pharmacy obtained at an Austro-Hungarian faculty. As of then, the opening of an increasing number of public civil pharmacies has begun. Concessions for the opening of pharmacies were mostly obtained by pharmacists from other parts of the Monarchy as there were no domestic ones available. The Law on Pharmacies was adopted in $1907 .^{5}$ After almost 30 years, the pharmacy service was regulated in a more comprehensive way, although public pharmacies still remained within the craft service.

The first public pharmacy with a graduated pharmacist was opened in Banja Luka in 1879. This also meant the closure of the Kalma Altarac pharmacy who had no diploma. He inherited the pharmacy from Isak Papo, one of the military doctors (hakims) who came to Banja Luka with the army and treated the citizens along the way. The second pharmacy was opened in 1890 by the pharmacist Otto Löschner, which was taken over by the pharmacist Tomo Mirković in $1907 .{ }^{6}$ Over 40 years, from the Austro-Hungarian occupation to the end of the First World War, only two pharmacies operated in the city despite the population growth. When the first pharmacy was opened, the city had 9,560 inhabitants, ${ }^{7}$ and in $1910,14,800$ inhabitants. ${ }^{8}$ An attempt to open the third pharmacy in 1912 was not realised, as the opinion regarding jeopardised survival of the existing pharmacies due to the predominantly poor population was submitted to the Pharmacy Guild by the two already operating pharmacists. The aim of this article is to present the family of pharmacists Brammer, whose three generations have run the pharmacy in Banja Luka since its founding in 1879 .

\section{First modern pharmacy in Banja Luka}

Moritz Brammer, a Hungarian Jew, opened the first modern pharmacy modelled on the European ones and was succeeded by his son and later grandchildren. He received the concession from the Military Command of the 2nd Army of the

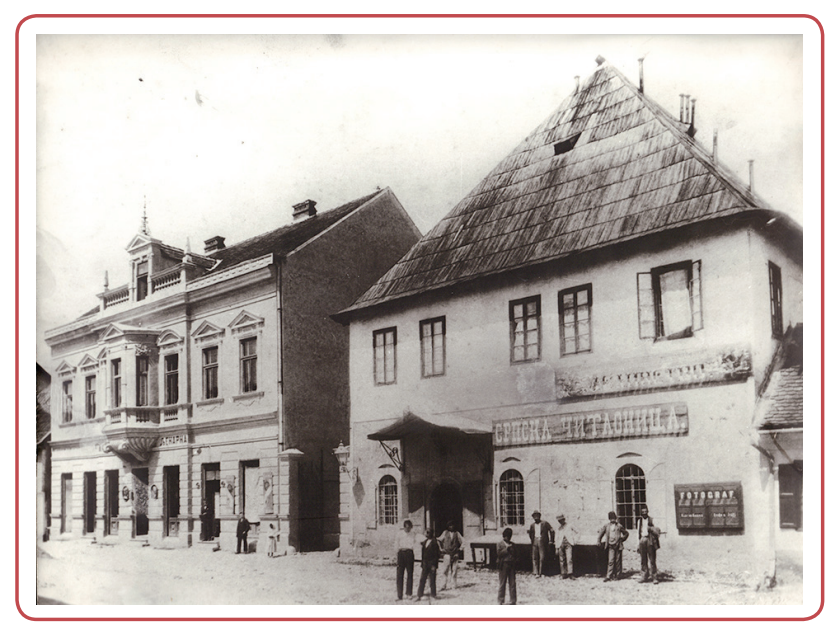

Figure 1: Brammer pharmacy (left), Serbian Reading Room (right), 1898-1899.

Austro-Hungarian Army on 30 December 1878 and opened the pharmacy on 1 April 1879. The house with the pharmacy was located at the beginning of the Gospodska street, next to the house where the Serbian Reading Room was (Figure 1). At the beginning of the 20th century a restaurant and cafe Balkan was built, ${ }^{6}$ and the spatial and decorative solutions of the pharmacy and cafe defined the Gospodska Street (Figure 2). The architectural forms and decorations of the pharmacy building, in terms of its representativeness and general construction concept, later served as a model for future buildings in this street. ${ }^{9}$

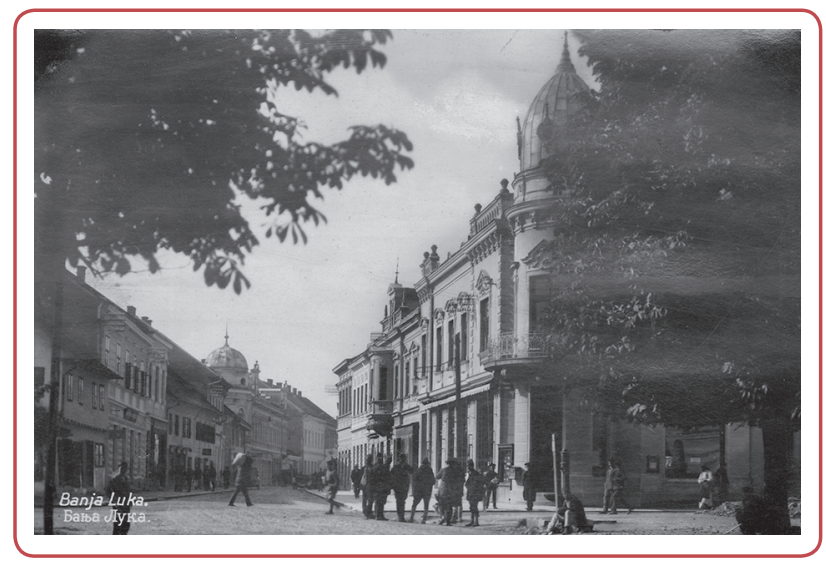

Figure 2: Cafe Balkan on the right corner, next to it Brammer's pharmacy with a protruding bay window, before 1930.

A written trace of the work of this pharmacy was found in advertisements in newspapers from that time. During the 19th century, advertising of various products available in pharmacies became more visible in daily newspapers, magazines and other publications, because the press became more accessible to the general population and advertising began to contribute significantly to their sales. Thus, various products for the care of 


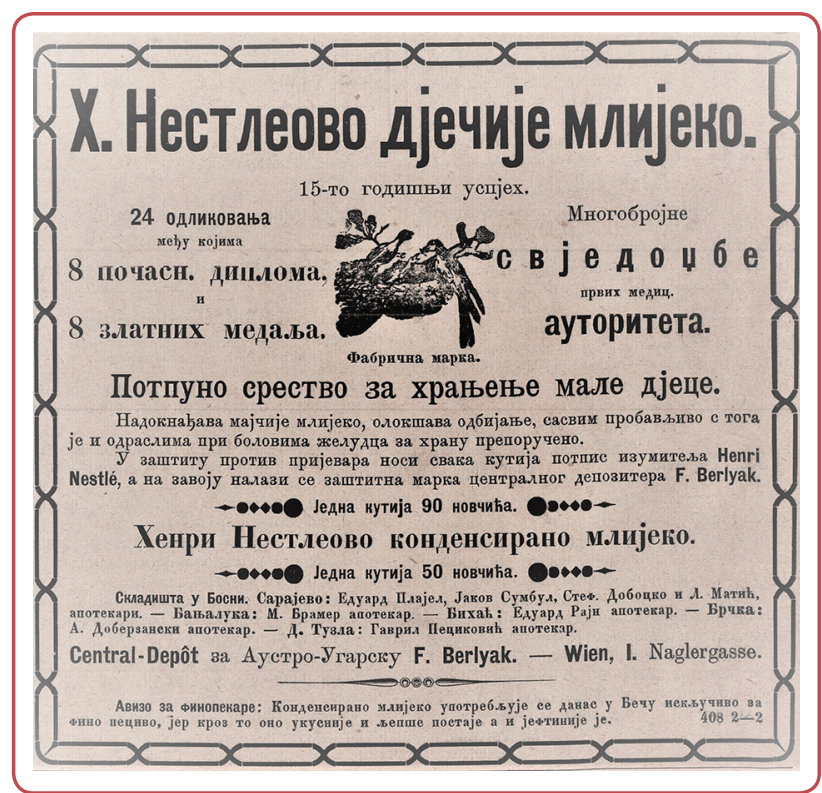

Figure 3: Advertisement for Nestle milk for children available also at Mr Brammer's pharmacy, 1887.

teeth, mouth and body of Dr Popp from Vienna, advertised in $1884^{10}$ and Nestle milk for children in 1887 (Figure 3) ${ }^{11}$ could also be found at the M. Brammer's pharmacy.

\section{The next generations of phar- macists of the Brammer family}

Robert Brammer (26 February 1870 - 22 February 1916) graduated on 28 July 1892 in Vienna. He inherited his father's pharmacy and by a Decision of 2 October 1892, the Provincial Government for Bosnia and Herzegovina granted him a concession for the further management of the pharmacy. ${ }^{6}$ The name of the pharmacy was "To the Golden Snake" (Zur Goldenen Schlange). It was registered in the Register of Independent Companies on 27 May $1893^{12}$ and, as a craft service, in the Trade Register of the City of Banja Luka as well. ${ }^{13} \mathrm{He}$ was married to Jozefina, née Büchler (20 March 1880 - 14 June 1959) and they had sons Ernest, Hans and Alfred, later also pharmacists. A document from the period of his work is shown in Figure 4. It is a notification sent to $\mathrm{Mr}$ Brammer by the Banja Luka District Government in May 1899 that he was sending the pharmacy's prescriptions for retaxation to the district physician Dr Januszewski (Figure 4). ${ }^{14}$ Drug bills for the medicines dispensed to the city hospital were later submitted for examination and retaxation, too. $^{15}$

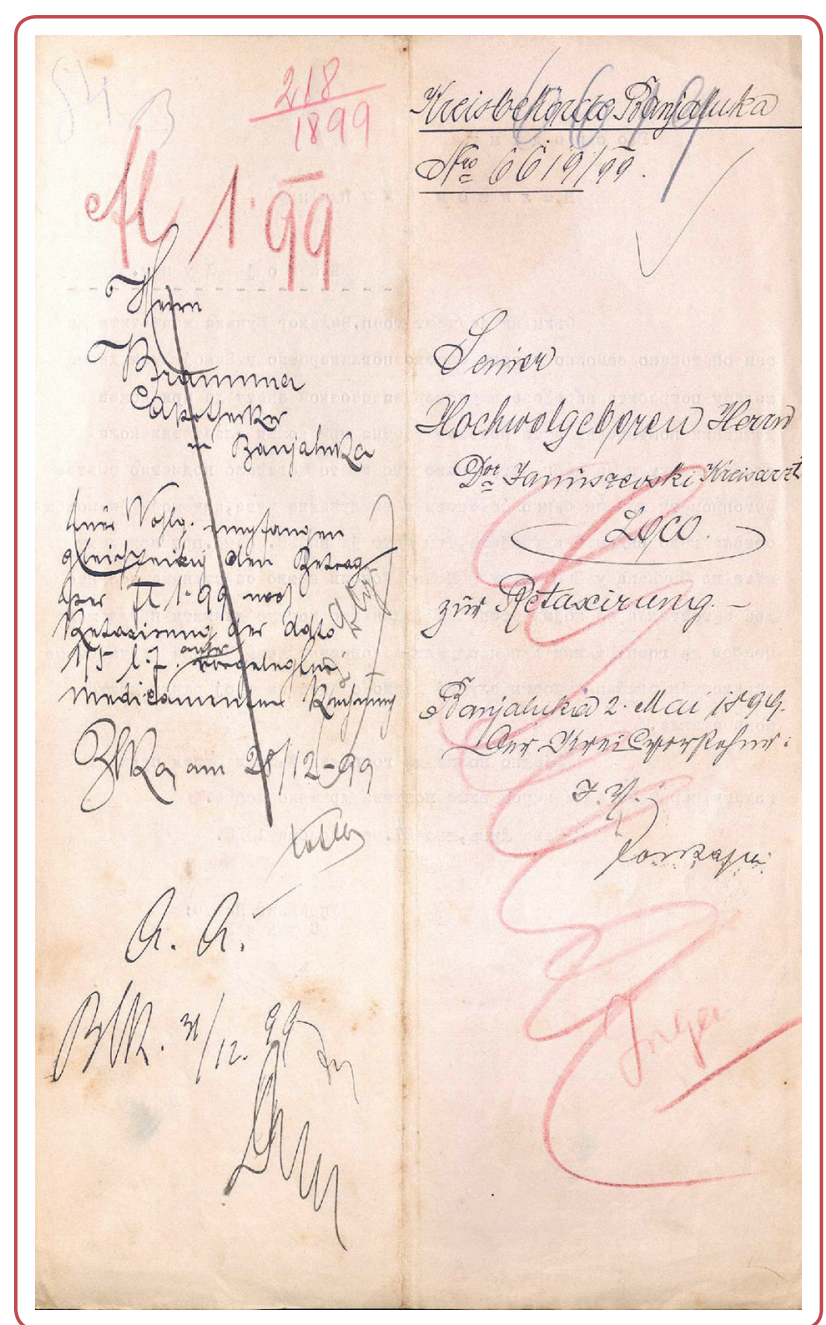

Figure 4: Pharmacist Robert Brammer's prescriptions sent for retaxation to a district doctor Januszewski, a cover letter, 1899.

He was a member of the Steering Board and vice-president of the Directorate the First Banja Luka Savings Bank Ltd. This was the first bank established in Banja Luka in 1894 and its founders and shareholders were also settlers, pharmacists Brammer and Löschner. Brammer was on the Steering Board from 1906 until his death, and a vice-president from $1912 .{ }^{16} \mathrm{He}$ was one of the founders of the Serbian Reading Room and the Directory of Founding Members preserved from 1914 was published in the newspaper the Vrbaske novine in 1938 as an example of helping cultural folk institutions that can serve as an incentive for the younger generation. ${ }^{17}$

Pharmacies were subject to inspections in accordance with regulations. According to the 1905 inspection report, the handling of the pharmacy was orderly and impeccable and the dispensing and sales of medicines was carried out properly (Figure 5). ${ }^{6}$ Subsequent examinations also showed a perfect condition without any objec- 


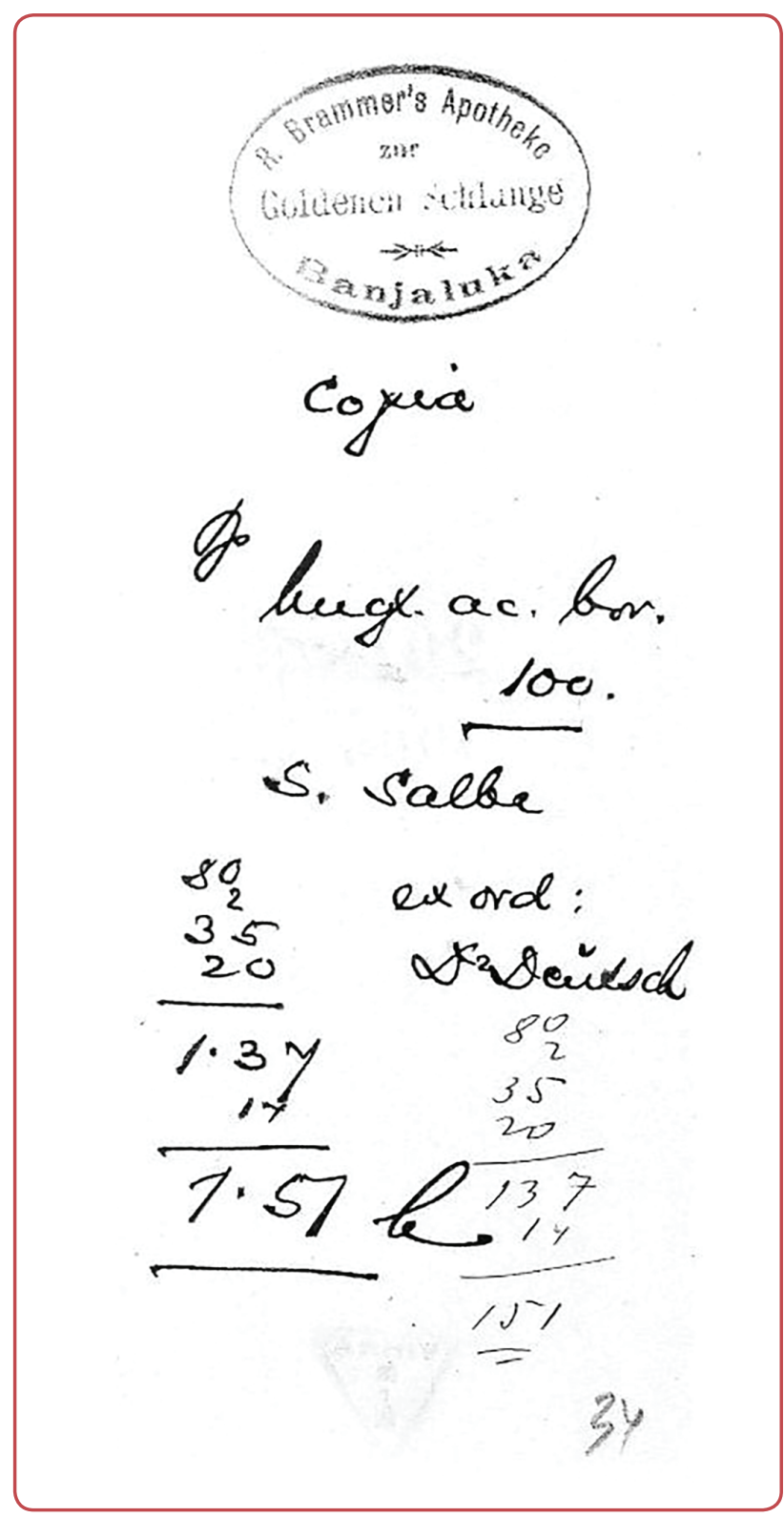

Figure 5: A prescription for a medicine dispensed at R. Brammer's pharmacy "Zur Goldenen Schlange" ("To the Golden Snake“), 1905.

tions from the commission to the work of the pharmacy. ${ }^{18}$ Brammer's hair water preparation was advertised in a newspaper (Figure 6). ${ }^{19}$

Robert Brammer has supported numerous charitable activities for the benefit of various societies and their beneficiaries through voluntary financial contributions. At a party held for the benefit of the Gajret, Sirotište and Fadilet Societies on 19 February 1914, he donated 10 Crowns, ${ }^{20}$ to the Fund for Widows and Orphans of Fallen Heroes in 1915, 100 Crowns, ${ }^{21}$ and 50 Crowns at a charity concert in favour of the Red Cross held the same year. At that time, Brammer was among those who donated larger sums. ${ }^{22}$

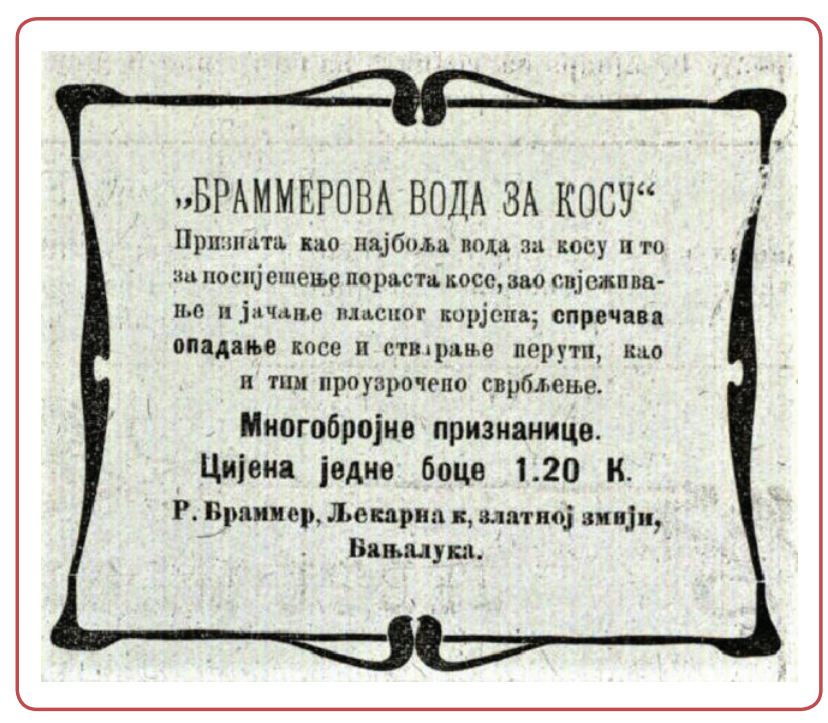

Figure 6: Advertisement for "Brammer hair water", 1906.

After the early death of Robert Brammer, the pharmacy owners became his widow Jozefina and their three underage sons. In that case pharmacy had to have a provisor who was a pharmacist. By the decision of the Provincial Government of 24 July 1916, the provisor of the pharmacy became Binim Bleiberg, born in Narayov (Galicia) and graduated in 1914 in Lawow. The pharmacy was registered in the Register of Socially-owned Companies on 16 June 1919, from which the underage sons were deleted on 21 April 1934. ${ }^{23}$

Robert Brammer's house and the Balkan cafe were demolished in 1930 to build the object of Ban's Palace (Banski Dvor). In 1936, the pharmacy moved to a building located across the former pharmacy. Built on two floors, it was among the taller and more modern ones. Jozefina Brammer, the owner of the house, addressed the city administration in 1935 with a request to be allowed to adapt the house, which was in a neglected construction condition. After the adaptation, the value of which was 60,000 dinars,$^{24}$ the pharmacy itself was larger, more spacious and gave the appearance of a metropolitan pharmacy. ${ }^{25}$ The house of Aleksandar Masleša, father of Veselin (revolutionary and People's Hero of Yugoslavia), was bought and adapted. ${ }^{26}$

The pharmacy was inhereted by Ernest Brammer, called Puba (22 September 1899 - 11 March 1960) (Figure 7, Figure 8). He attended the Great Real Gymnasium in Banja Luka in the school year 1909/10 and graduated in 1917/18. ${ }^{27}$ He studied pharmacy in Zagreb (1919-1921), 


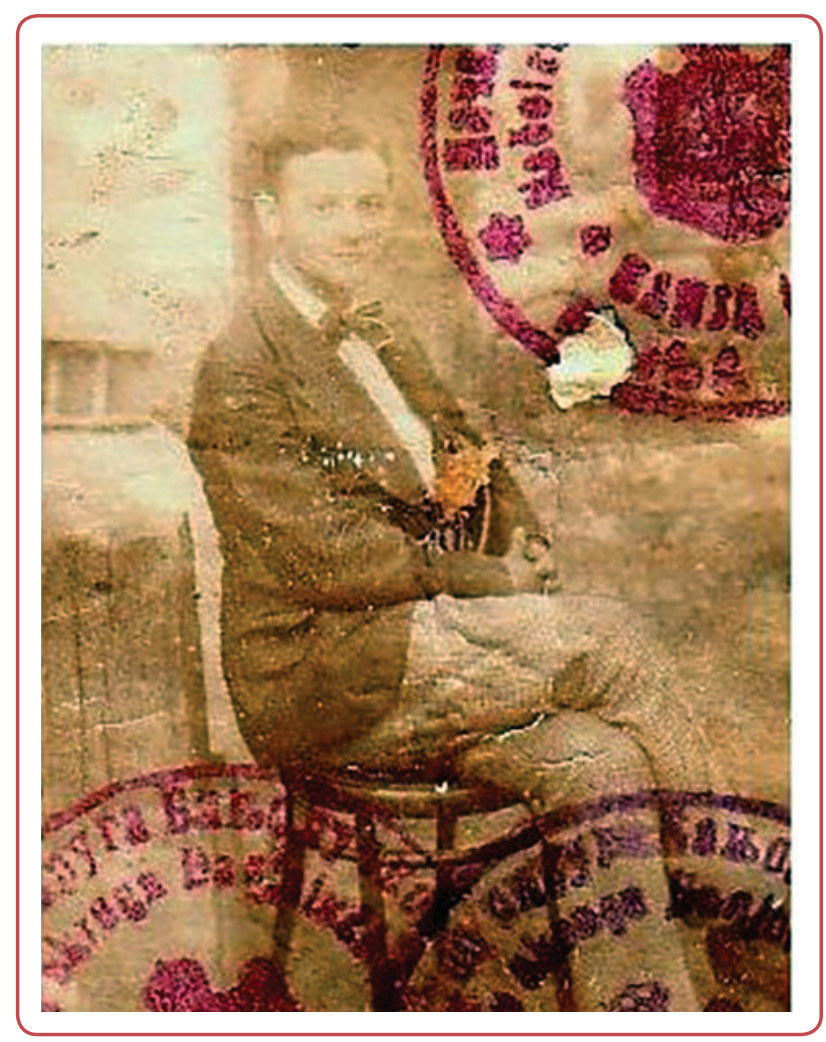

Figure 7: Ernest Brammer, 1924.

graduated with honours in 1921 and began working in his father's pharmacy the same year. ${ }^{28}$ In a personal description of the request for issuance of the passport in 1921 was it stated that he was of medium height, had oval face, black hair and eyes and wore glasses. ${ }^{29} \mathrm{He}$ often travelled to Germany, Austria, Italy, Czechoslovakia, France and Hungary for conducting business.

He was married to Franciska Šolić (1903-1995), called Zula, and had no children. Since 1914, the Brammer pharmacy has had a telephone with the telephone number 9. ${ }^{30}$ In 1933, Ernest Brammer was elected a member of the Steering Committee of the Tennis Club. ${ }^{31}$ He was also engaged in philately. In 1937 he was elected member of the Supervisory Board of the Philatelist's Association ${ }^{32}$ and was a member of the Philatelist's Federation of Bosnia and Herzegovina. ${ }^{33}$

On the list of Jews arrested and separated for transportation to the Jasenovac concentration camp, composed on 29 July 1941 by the Ustasha Police Directorate, he was also registered, but was released from prison by Anton Rebac. During the operation of the Ustasha headquarters, the pharmacies of the Jewish owners had commissioners, who paid them a monthly fee for working in the pharmacy. The owners and trust-

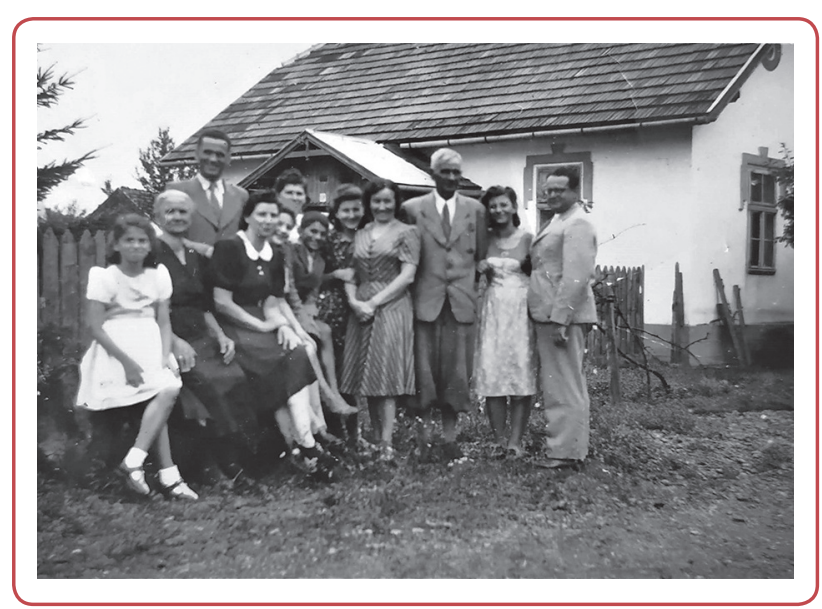

Figure 8: Ernest Bramer, first on the right, around the 1950 s.

ees of the Brammer pharmacy were pharmacists Adem Kovačević and Slavko Flegar. The decision to return the pharmacy ownership to Ernest Brammer was made in 1945. A two-storey family house at Veselina Masleše Street 18, with two apartments and business premises, came under nationalisation in 1958 when the pharmacy was nationalised. ${ }^{27}$

Ernest Brammer worked in his father's and then his own pharmacy from 1921 to 1944, as an intern, a pharmacist and the pharmacy provisor. From then until 1945, he worked in the free territory in partisan pharmacies in Sanski Most, Jajce and Travnik and in his own pharmacy until takeover by the City Pharmacies Banja Luka in 1948. He was admitted to the civil service with the title of pharmacist and was recognised for his work in the private service in the period 1921-1948. In the City Pharmacies Banja Luka, he performed professional-scientific, organisational, administrative and practical work. As he had over 28 years of service in his profession, in 1951 he was exempted from taking the professional exam. In 1953 he was appointed as director of the Head Office of the City Pharmacies in Banja Luka. ${ }^{28}$ He was buried in the family tomb at the Mirogoj Cemetery in Zagreb, together with his parents, wife and brother Alfred.

Hans Brammer (22 September 1903 - 13 April 1989) completed the First Public School for Boys (1909 - 1913), the Great Real Gymnasium (1913 1921) and gratuated pharmacy in 1925 in Zagreb. He was fluent in German, English, Hebrew and French. As of 1922 he worked in his father's pharmacy. ${ }^{27}$ In a personal description of the request for issuance of the passport in 1928 was stated that he was of medium height, had oval face, 
brown hair and eyes and wore glasses. He often went on scientific and business trips to Austria, Italy, Hungary, Switzerland and Germany. ${ }^{34}$ From a young age, he participated in the work of the $\mathrm{Zi}-$ onist youth in Banja Luka. ${ }^{35}$ He married Flora Salom in 1930 (29 November 1903 - ?) and has lived in Zagreb ever since. They had a daughter, Maja.

During 1930, he expanded the activities of the pharmacy, which has since operated as a medical drugstore called Vesna. By the decision of the Ustasha headquarters, the shop was sold to Slavica Maričić on 10 June $1941 .{ }^{36}$ With an engineer A. Miljević, he was a co-owner of the chemical-pharmaceutical company Mibra in Zagreb, 13 Svačič Square. ${ }^{37}$ In the interwar period (19391941) and after 1945 he was a co-owner of Saint Trinity Pharmacy in 43 Ilica Street (Figure 9). ${ }^{38}$ This pharmacy still operates at the same address within the City Pharmacy Zagreb, and its Art Nouveau appearance has not been preserved over time.

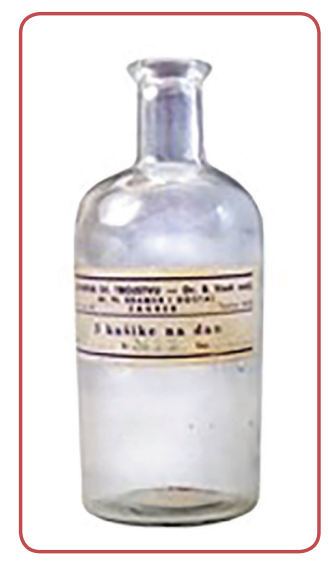

Figure 9: Medicine bottle from the Saint Trinity Pharmacy, Zagreb, coowned by Hans Brammer, around 1935.

He was arrested in Zagreb in 1943 and detained in a military prison for six months and afterwards sent to the Military Pharmacy in Bosanski Brod. In 1944, he escaped to the free territory , controlled by the Yugoslav Partisans (officially, National Liberation Army and Partisan Detachments of Yugoslavia) and was a pharmacy officer in the XII Assault Division. ${ }^{27} \mathrm{He}$ emigrated to Israel in 1949 and settled in Jerusalem, where he opened a pharmacy in the city centre. He was also a journalist and a writer. He published poems, short novels, dramas, literary essays, articles and stories in many newspapers and magazines. He wrote poetry and prose in the newspapers Gideon and Hanoir, dealt with Jewish history and collaborated with Pinkas Hakehilot, the Encyclopaedia of Jewish Communities in Yugoslavia. The pharmacy, next to his home, served for years as a meeting place for members of the Bulletin of the Associ- ation of Immigrants from the Former Yugoslavia (Hitahdut Olej Jugoslavia) in Israel called GešerMost (the Bridge) whose one of the founders and editor he was. ${ }^{35}$

Alfred Brammer (30 August 1912 - 18 July 1985 ) graduated in the school year 1929/30 at the Real Gymnasium in Banja Luka. ${ }^{27}$ He graduated pharmacy in 1938 in Zagreb, and was the owner of a pharmacy and a store of hygienic and sanitary materials in Zagreb, Frankopanska Street, before Second World War. He joined the Yugoslav National Army as a pharmacy officer of the XV division. After the war he returned to Zagreb, ${ }^{35}$ remained in the Army and retired as a Colonel, Medical Corps. He was a holder of four military decorations. ${ }^{39}$

\section{Conclusion}

The Brammers were one of the famous families in Banja Luka, who contributed a lot to the cultural and social development of the city in the time in which they lived. With the pharmacy business they positively contributed to the development of the health situation in the city over time, as well as to the community development with their different interests, together with the contemporaries they lived with.

\section{Acknowledgements}

None.

\section{Conflict of interest}

None.

\section{References}

1. Cirkularerlass der Landesregierung in Sarajevo vom 24. Februar 1879., Nr. 2080 pol., betreffend die Organisirung des Sanitätsdienstes [Circular Decree of the Provincial Government in Sarajevo of February 24th, 1879, Nr. 2080 pol., regarding the organization of the medical service]. Sammlung der für Bosnien und die 
Hercegovina erlassenen Gesetze, Verodnungen und Normalweisungen. I Band. Wien; 1880. p. 89-91. German.

2. Đuričić A, Elazar S. Pregled istorije farmacije Bosne i Hercegovine [An overview of the history of pharmacy in Bosnia and Herzegovina]. Sarajevo: Grafičar; 1958. p. 267. Serbo-Croatian.

3. Poloni Ž. Češi v Sarajevu 1878-1918 [Czech people in Sarajevo 1878-1918] [Internet][master's thesis]. Olomouc: Palacký University; 2009. [cited 2020 Sep 19] p. 58, 104. Available from: https://theses.cz/id/k7i6n2/. jm.web.pdf.

4. Verordnung der Landesregierung in Sarajevo vom 19. Februar 1879. Nr. 1999 pol., betreffend die Regelung des Apothekergewerbes in Bosnien und der Hercegovina [Regulation of the Provincial Government in Sarajevo on 19 February 1879. Nr. 1,999 pol., regarding the regulation of the pharmacy profession in Bosnia and Hercegovina]. Sammlung der für Bosnien und die Hercegovina erlassenen Gesetze, Verodnungen und Normalweisungen. I Band, Wien; 1880. p. 91-92. German.

5. Red za ljekarnice u Bosni i Hercegovini [Law on pharmacies in Bosnia and Herzegovina]. Glasnik zakona i naredaba za Bosnu i Hercegovinu. Godina 1907. Sarajevo; 1909. p. 254-73. Croatian.

6. Marković-Peković V. Banjalučke javne apoteke u Austrougarskom periodu [Public Pharmacies in Banja Luka in the Austro-Hungarian period]. Glasnik Udruženja arhivskih radnika Republike Srpske [Internet] 2011 [cited 2020 Sep 15];3:137-48. Available from: http://www.uarrs-arhivisti.org/Upload/Udruzenje/29_4_2011_25_Glasnik_UARRS_3.pdf. Serbian.

7. Katastral-Schatzungs-Direction für Bosnien und die Hercegovina. Štatistika miesta i pučanstva Bosne i Hercegovine [Statistics of places and populations of Bosnia and Herzegovina].[CD-ROM]. Sarajevo; 1880. p.33. Croatian.

8. Zemaljska vlada za Bosnu i Hercegovinu. Rezultati popisa žiteljstva u Bosni i Hercegovini od 10. oktobra 1910 [Results of the October 10, 1910 Population Census in Bosnia and Herzegovina]. [CD-ROM]. I Odsjek. Sumarni pregledi. Sarajevo: Zemaljska vlada; 1912. p. 5. Croatian.

9. Ševo Lj. Urbanistički razvoj Banje Luke [The urban development of Banja Luka]. Banja Luka: Biblioteka Baština; 1996. p. 104. Serbian.

10. Anatherin-, Zahn- und Mundwasser von Dr. Popp [Anatherine, Tooth and Mouthwash from Dr. Popp]. Sarajevski list. 1884 Jan 12; No.4. Advertisements:6. German.

11. Nestleovo dječije mlijeko [Nestle milk for children]. Sarajevski list. 1887 Jun 19; No.70. Advertisements:4. Serbian.

12. Registar inokosnih firmi [Register of independent companies]. Okružni sud Banja Luka, 1883-1911. Ordinal No.601. Arhiv Republike Srpske, Banja Luka. Croatian.

13. Registar obrta, Banja Luka-grad [Trade register, Banja Luka-city]. Okružni sud Banja Luka,1907-1911. Ordinal No. 44. Arhiv Republike Srpske, Banja Luka. German.

14. Okružnom ljekaru šalju se na retaksaciju recepti apoteke Brammer iz Banjaluke. [Prescriptions from the Brammer pharmacy from Banja Luka are being sent to the district doctor for retaxation]. Kreisbehörde Banja Luka. Regesta 1899. Document No.84 (218/1899). Arhiv Republike Srpske, Banja Luka. German.

15. Dostavljanje na pregled i retaksaciju računa apotekara Brammera za lijekove isporučene gradskoj bolnici [Submission for review and retaxation of pharmacist Brammer's invoice for medicines delivered to the city hospital]. Kreisbehörde Banja Luka. Regesta 1904. Document No.70 (76/1904). Arhiv Republike Srpske, Banja Luka. German.

16. Registar firmi-društva [Register of socially-owned companies]. Okružni sud Banja Luka, 1884-1911. Ordinal No.102. Arhiv Republike Srpske, Banja Luka. Serbian.

17. Imenik članova utemeljača Srpske čitaonice u Banjoj Luci pred početkom svetskog rata u 1914. godini [Directory of the founding members of the Serbian Reading Room in Banja Luka before the beginning of the World War in 1914] [CD-ROM]. Vrbaske novine 1938 May 1; No.1426. Gradska kronika: 3. Serbian.

18. Zapisnik o pregledu javne apoteke Roberta Brammera od 20.I 1919. u Banjoj Luci [Inspection report of Robert Brammer's public pharmacy dated 20 Jan 1919 in Banja Luka]. Opšta. Document Nr. 50814/19. Arhiv Bosne i Hercegovine. Croatian.

19. Brammerova voda za kosu [Brammer hair water]. Naš život 1906 end of Jun; No.1. Advertisements: 2. Serbian.

20. Zabava u Banjaluci [Party in Banja Luka][Internet] Gajret 1914 Apr 1; No.4; [cited 2020 Sep 19]. Gajretov glasnik: 65. Available from: http://kolekcije.nub.ba/items/ show/381.web.pdf.

21. Za udovice i siročad palih junaka [For the widows and orphans of fallen heroes]. Sarajevski list 1915 Jul 14; No.196; p. 2. Croatian.

22. Dobrotvorni koncerat u korist „Crvenog križa“u Banjoj Luci [Charity concert in favor of the "Red Cross" in Banja Luka]. Sarajevski list 1915 Sep 17; No.252.Vijesti iz pokrajine: 2 . Croatian.

23. Registar firmi-društva [Register of socially-owned companies].Okružni sud Banja Luka, 1915-1932.0rdinal No. 357. Arhiv Republike Srpske, Banja Luka. Serbian.

24. Jozefina Bramer, ul. Kralja Alfonsa br. 18-adaptacija kuće [Jozefina Brammer, Kralja Alfonsa Street 18 -house renovation]. Gradsko poglavarstvo Banja Luka, 1936. Document No.120/36. Arhiv Republike Srpske, Banja Luka. Serbian.

25. Preselenje apoteke Bramer [Relocation of Brammer Pharmacy].[CD-ROM]. Vrbaske novine 1936 May 27; No. 1002. Gradska kronika: 3. Serbian.

26. Puvačić Z. Stara Banja Luka [Old Banja Luka]. Beograd: Akademija Nova; 2001. p. 66. Serbian.

27. Danon J, Stošić V. Memoari na holokaust Jevreja Krajine [Memoars on Holocaust of the Jews from Bosanska Krajina][Internet]. Banja Luka: Jevrejska opština Banja Luka; 2010. Chapter: II dio-jevrejske porodice, p.190-3; [cited 2020 Sep 22]. Available from: http://www.jevrejskadigitalnabiblioteka.rs/handle/123456789/1272. web.pdf. Serbian.

28. Ernest Brammer, magistar farmacije, službenički dosije [Ernest Brammer, pharmacist, clerical file]. Gradski narodni odbor Banja Luka, 1949. Document B-58. Arhiv Republike Srpske, Banja Luka. Serbian.

29. Ernest Bramer, student iz Banjaluke, izdavanje pasoša [Ernest Brammer, a student from Banja Luka, issuance of a passport]. Okružna oblast Banja Luka, Putne isprave radi studiranja 1921-1922. Document No. 73 (8371/1921). Arhiv Republike Srpske, Banja Luka. Serbian.

30. Bosanski glasnik. Sarajevo: carske i kraljevske dvorske i državne štamparije; 1914. Chapter: V.Odsjek. Popis abonenata javne telefonske mreže u Banjoj Luci [List of subscribers of the public telephone network in Banja Luka]. p. 378. Muzej Republike Srpske. Croatian.

31. Godišnja skupština banjalučkog Tenis kluba [Annual Assembly of the Banja Luka Tennis Club].[CD-ROM]. Vrbaske novine 1933 Mar 29; No. 91. Sport:10. Serbian. 
32. Skupština Filatelističkog kluba [Assembly of the Philatelist's Association].[CD-ROM].Vrbaske novine 1937 Feb 26; No.1218:p. 2. Serbian.

33. Almanah hrvatskog filatelističkog društva. Savez filatelista Bosne i Hercegovine [Federation of Philatelists of Bosnia and Herzegovina]. Zagreb; 1951. p. 131. Croatian.

34. Molba Hansa Brammera za izdavanje putne isprave [Hans Brammer's application for issuance of a passport]. Veliki župan Vrbaske banovine, Banja Luka, Izdavanje putnih isprava 1928. Document No.857 (3445/28). Arhiv Republike Srpske, Banja Luka. Serbian.

35. Židovski biografski leksikon [Jewish biographical lexicon][Internet] Zagreb: Leksikografski zavod Miroslav Krleža. [online izdanja]. Bramer, Hans. [cited 2020 Sep 23] Available from: https://zbl.lzmk.hr/?p=2890.web. pdf. Croatian.
36. Iskaz židovskih radnji 31.XII 1941. [List of Jewish shops]. Zbirka varia 330-004-027. Ordinal No.6. Arhiv Republike Srpske, Banja Luka. Croatian.

37. Privredni adresar Kraljevine Jugoslavije [Commercial Address Book of the Kingdom of Yugoslavia]. Beograd: Zavod za unapređivanje spoljnje trgovine pri Ministarstvu trgovine i industrije; 1932.p. 416, 250. Serbian.

38. Fatović-Ferenčić S, Ferber Bogdan J. Ljekarna K Sv. Trojstvu: izgubljeni sjaj zagrebačke secesije. Medicus [Internet] 2007 [cited 2020 Sep 15]; 16(1):121-8. Available from: https://hrcak.srce.hr/23319. web.pdf. Croatian.

39. Romano J. Jevreji Jugoslavije 1941-1945. Žrtve genocida i učesnici narodnooslobodilačkog rata [Jews of Yugoslavia 1941-1945 victims of genocide and freedom fighters] [Internet]. Beograd: Savez jevrejskih opština Srbije; 1980. [cited 2020 Sep 15]. p.194. Available from: http://jevrejskadigitalnabiblioteka.rs/handle/123456789/651.web.pdf. Serbian. 